\title{
ANALISIS AMMI DENGAN RESPON GABUNGAN PADA UJI STABILITAS TANAMAN PADI GOGO DI KABUPATEN PACITAN*
}

\author{
Abdullah Ilman Fahmi ${ }^{1}$, Rahma Anisa ${ }^{2 \ddagger}$, Anang Kurnia ${ }^{3}$ \\ ${ }^{1}$ Dept. of Statistics, IPB University, Indonesia, ilmanfahmi27@gmail.com \\ ${ }^{2}$ Dept. of Statistics, IPB University, Indonesia, r.rahma.anisa@gmail.com \\ ${ }^{3}$ Dept. of Statistics, IPB University, Indonesia,anangk@apps.ipb.ac.id \\ ${ }^{\ddagger}$ corresponding author
}

Indonesian Journal of Statistics and Its Applications (eISSN:2599-0802)

Vol 3 No 1 (2019), 1 - 17

Copyright (c) 2019 Abdullah Ilman Fahmi, Rahma Anisa, and Anang Kurnia. This is an open-access article distributed under the Creative Commons Attribution License, which permits unrestricted use, distribution, and reproduction in any medium, provided the original work is properly cited.

\begin{abstract}
Gogo rice is one of the results of various rice cultivation development by planting in a dry land. Gogo rice is expected to give yield a better production of paddy in dry rice fields. The varieties Inpago 7, Inpago 8, Inpago 8 IPB, Inpago 9, Inpago 10, Situ Gintung, Situ Patenggang, Situ Bagendit, Gajah Mungkur, Slengreng TG, Slegreng GK, Srijaya, Towuti, Merah Wangi, dan Inpari 24 were used in this study. This study aims to identify the Gogo rice varieties that are stable and superior in six Pacitan Garden Experimental Plant locations based on a combined respon using the AMMI method. The AMMI analysis combines an additive variety analysis as the main effects of treatment with multiple principle component analysis by bilinier modeling for interaction efffect. This study used two combined responses, which described the plant productivity and the resistancy. The result of this study explained that some varieties, Inpago 8, Inpago 10, and Situ Patenggang, were stable varieties in all planting location based on the combined responses. According to productivity stability and plant resistancy superior gogo rice variety is Inpago 8 and Inpago 10.
\end{abstract}

Keywords: AMMI analysis, multilocation, gogo rice.

*Received Oct 2018; Accepted Nov 2018; Published online on Feb 2019 


\section{Pendahuluan}

\subsection{Latar Belakang}

Padi gogo merupakan salah satu ragam budidaya padi yaitu penanaman padi dilahan kering. Padi gogo umumnya ditanam sekali setahun pada awal musim hujan. Rendahnya produksi padi gogo juga disebabkan masih banyaknya yang menanami lahan kering dengan padi gogo varietas lokal yang berumur panjang. Menurut Suwarno et al. (2008) proporsi padi gogo dalam perpadian nasional masih rendah $9 \%$ dari segi luas areal tanam dan $5 \%$ dari segi produksi. Meskipun demikian padi gogo mempunyai potensi untuk mendukung peningkatan produksi padi nasional, baik melalui peningkatan hasil maupun perluasan areal. Padi gogo diharapkan dapat menghasilkan produksi yang lebih besar pada lahan sawah kering.

Balai Pengkajian Teknologi Pertanian melakukan percobaan multilokasi terhadap 15 varietas padi gogo sebagai upaya untuk menghasilkan varietas tanaman yang unggul. Penggunaan varietas unggul merupakan salah satu faktor yang berpengaruh terhadap produktifitas padi. Purba dan Giametri (2017) menjelaskan bahwa beberapa keuntungan yang dapat diperoleh dari penggunaan varietas unggul diantaranya adalah mengurangi jumlah pemakaian benih dan tanam ulang serta memiliki daya kecambah dan tumbuh yang tinggi.

Hasil percobaan multilokasi sudah banyak dikembangkan dengan menggunakan metode analisis AMMI. Beberapa yang menggunakan metode ini seperti Sumertajaya (1998) dan Sujiprihati et al. (2006). Analisis AMMI (Additive Main Effect and Multiplicative Interaction) adalah metode analisis data percobaan multilokasi yang menggabungkan antara analisis ragam aditif bagi pengaruh utama perlakuan dan analisis komponen utama ganda dengan pemodelan bilinier bagi pengaruh interaksi (Mattjik dan Sumertajaya (2013)). AMMI baik digunakan untuk uji multilokasi, sehingga dari setiap varietas dapat diketahui kestabilan terhadap masing - masing lokasi. Pada percobaan ini akan digunakan lima morfologi tanaman pagi gogo sebagai dasar penggabungan respon untuk diketahui kestabilan varietas terhadap semua lokasi tanam.

\subsection{Tujuan}

Tujuan dari penelitian ini adalah:

1. Mengidentifikasi varietas padi gogo yang stabil di enam lokasi Taman Tanaman Percobaan (TTP) Pacitan berdasarkan respon gabungan dengan menggunakan metode AMMI.

2. Menentukan varietas padi gogo yang unggul di enam lokasi TTP Pacitan berdasarkan kestabilan nilai produksi dan daya tahan tanaman.

\section{Tinjauan Pustaka}

\subsection{Percobaan Multilokasi}

Percobaan multilokasi merupakan suatu perancangan percobaan yang serupa dari beberapa lokasi dan memiliki perlakuan yang sama. Model linier untuk percobaan 
multilokasi dengan menggunakan rancangan acak kelompok (Rumakubis (2012);Idris dan Baharudin (2015)) adalah sebagai berikut:

$$
Y_{i j k}=\mu+G_{i}+L_{j}+B_{k(j)}+(G L)_{i j}+\varepsilon_{i j k}
$$

Keterangan:

$Y_{i j k}$ : respon varietas ke-i pada lokasi ke-j dalam ulangan ke-k

$\mu$ : nilai rataan umum

$G_{i}$ : pengaruh varietas ke-i, $\mathrm{i}=1,2, \ldots \mathrm{s}$

$L_{j}$ : pengaruh lokasi ke-j, $\mathrm{j}=1,2, \ldots \mathrm{t}$

$B_{k(j)}$ : pengaruh kelompok ke-k tersarang pada lokasi ke-j, $\mathrm{k}=1,2 \ldots \mathrm{r}$

$(G L)_{i j}$ : pengaruh interaksi varietas ke-i dan lokasi ke-j

$\varepsilon_{i j k}$ : pengaruh sisaan dari varietas ke-i dalam kelompok ke-k yang dilakukan di lokasi ke-j

\subsection{Penggabungan Respon}

Penggabungan respon merupakan salah satu cara untuk melihat daya adaptasi tanaman secara komprehensif berdasarkan penyederhanaan analisis. Penelitian ini menggunakan dengan metode range equalization dalam penggabungan respon. Metode ini adalah salah satu metode penggabungan respon yang dapat menjelaskan respon - respon asal dengan baik (Sumertajaya (2005)). Range equalization digunakan untuk memperoleh respon gabungan dengan mencari informasi nilai minimun dan maksimum dari data awal. Nilai SDII (sub dimension indicator index) perlu dihitung terlebih dahulu untuk mendapatkan nilai respon gabungan. Untuk respon ke-a dan amatan ke-b, SDII dapat dihitung sebagai berikut:

$$
S D I I_{a}=\frac{Y_{a b}-Y_{a .}(\min )}{Y_{a .}(\max )-Y_{a .}(\min )}
$$

dengan,

$a: 1,2, \ldots p$

$b: 1,2, \ldots n$

$p$ : banyaknya respon

$n$ : banyaknya amatan

Selanjutnya nilai respon gabungan dapat dihitung dengan persamaan berikut:

$$
\text { Respongabungan }=\sum_{a=1}^{p} \frac{S D I I_{a}}{p}
$$

\subsection{AMMI (Additive Main Effect and Multiplicative Interaction)}

Analisis AMMI (Additive Main Effect and Multiplicative Interaction) adalah metode analisis data percobaan multilokasi yang menggabungkan antara analisis ragam aditif bagi pengaruh utama perlakuan dan analisis komponen utama ganda dengan pemodelan bilinier bagi pengaruh interaksi (Mattjik dan Sumertajaya (2013)). Model AMMI secara lengkap dapat dituliskan sebagai berikut:

$$
Y_{i j k}=\mu+\alpha_{i}+\beta_{j}+\tau_{k(j)}+\sqrt{\lambda_{n}} \varphi_{i n} \rho_{j n}+\delta_{i j}+\varepsilon_{i j k}
$$


keterangan:

$Y_{i j k}$ : respon dari varietas ke-i, lokasi ke-j, dan kelompok ke-k

$\mu$ : nilai rataan umum

$\alpha_{i}$ : pengaruh varietas ke-i, $\mathrm{i}=1,2, \ldots, \mathrm{s}$

$\beta_{j}$ : pengaruh lokasi ke-j, $\mathrm{j}=1,2, \ldots, \mathrm{t}$

$\tau_{k(j)}$ : pengaruh kelompok ke-k tersarang pada lokasi ke-j, $\mathrm{k}=1,2, \ldots, \mathrm{r}$

$\sqrt{\lambda_{n}}$ : nilai singular untuk komponen bilinier ke-n, $\mathrm{n}=1,2, \ldots, \mathrm{m}$

$\varphi_{i n}$ : pengaruh ganda varietas ke-i komponen bilinier ke-n

$\rho_{j n}$ : pengaruh ganda lokasi ke-j komponen bilinier ke-n

$\delta_{i j}$ : simpangan dari pemodelan linier

$\varepsilon_{i j k}$ : pengaruh acak pada varietas ke-i, lokasi ke-j, dan kelompok ke-k

Adapun tahapan dalam analisis AMMI adalah sebagai berikut:

1. Pembentukan matriks pengaruh interaksi $(\mathbf{Z})$

Penduga pengaruh interaksi yaitu $(\alpha \beta)_{i j}=\bar{Y}_{i j .}-\bar{Y}_{i . .}-\bar{Y}_{. j .}-\bar{Y}_{\text {... Selanjutnya, }}$ pengaruh interaksi disusun menjadi matriks sebagai berikut:

$$
\mathbf{Z}=\left[\begin{array}{ccc}
\alpha_{1} \beta_{1} & \cdots & \alpha_{1} \beta_{t} \\
\vdots & \ddots & \vdots \\
\alpha_{s} \beta_{1} & \cdots & \alpha_{s} \beta_{t}
\end{array}\right]
$$

2. Melakukan penguraian nilai singular

Penguraian nilai singular dilakukan untuk menduga pengaruh interaksi antara varietas dengan lokasi. Penguraian nilai singular terhadap matriks pengaruh interaksi $\mathbf{Z}$ dengan bentuk perkalian matriks sebagai berikut:

$$
\mathbf{Z}=\mathbf{U L A}^{\prime}
$$

keterangan:

Z : matriks data terpusat $s \times t$

$\mathbf{U}$ : matriks ortonormal ( $\mathbf{U}^{\prime} \mathbf{U}=\mathbf{A}^{\prime} \mathbf{A}=I_{r}$ ) berukuran $s \times r, r$ adalah rank $\mathbf{Z}$

$\mathbf{L}$ : matriks diagonal berukuran $r \times \mathrm{x}$ dengan diagonal utamanya berupa akar dari akar ciri positif bukan nol dari matriks Z'Z

A : matriks ortonormal $\left(\mathbf{A}^{\prime} \mathbf{A}=I_{r}\right)$ berukuran $t \times r$ Diagonal utama matriks $\mathbf{L}$ selanjutnya disebut nilai singular

3. Menghitung nilai komponen untuk varietas dan lokasi

Nilai komponen varietas dan lokasi dapat diperoleh dari penguraian nilai singular yang berbentuk $\mathbf{Z}=\mathbf{G H}$ '. Penguraian nilai singular ini diawali dengan mendefinisikan matriks diagonal $(L)^{m}(0 \leq \mathrm{m} \leq 1)$ yang elemen-elemen diagonalnya adalah elemen-elemen matriks $L$ dipangkatkan $m$. Pendefinisian matriks $(L)^{1}-m$, $G=U(L)^{m}$, dan $H=A(L)^{1}-m$ sehingga nilai komponen varietas merupakan kolom-kolom matriks $\mathbf{G}$ dan nilai komponen lokasi adalah kolom-kolom matriks $\mathbf{H}$ dengan $m$ sebesar 0.5 . 
4. Menentukan banyaknya komponen utama interaksi (KUI) yang nyata dengan metode posdictive success

Metode posdictive success (keberhasilan total) berkaitan dengan kemampuan suatu model tereduksi dalam melakukan pendugaan data yang digunakan untuk membangun model tersebut. Indikator yang digunakan dalam menentukan banyaknya komponen utama adalah banyaknya KUI yang nyata pada uji-F analisis ragam (Mattjik dan Sumertajaya (2013)).

5. Membuat biplot AMMI Biplot merupakan salah satu upaya peragaan grafik dari matriks dalam suatu plot yang berisi vektor-vektor saling tumpang tindih dalam ruang dimensi dua (Hadi dan Sa'diyah (2004)). Pola tebaran titik-titik yang disajikan biplot merupakan hasil penguraian nilai singular yang diplotkan antara satu komponen varietas dengan komponen lokasi secara simultan (Sujiprihati et al. (2006)). Terdapat dua Biplot AMMI yang digunakan pada analisis AMMI yakni Biplot AMMI1 dan Biplot AMMI2. Biplot pada nilai komponen utama pertama (KUI1) dengan rataan respon merupakan Biplot AMMI1. Biplot AMMI2 merupakan biplot antara komponen utama pertama (KUI1) dengan komponen utama kedua (KUI2) ketika komponen utama interaksi kedua signifikan.

Biplot AMMI1 menunjukkan bahwa varietas memiliki daya adaptasi yang baik pada suatu lokasi jika varietas dan lokasi berinteraksi positif. Biplot AMMI2 merupakan penggambaran pengaruh interaksi antara varietas dengan lokasi. Titik-titik amatan yang arahnya sama mengindikasikan adanya interaksi positif diantara titik-titik amatan tersebut, sebaliknya titik-titik yang berbeda arahnya menunjukkan bahwa ada interaksi negatif diantara titik-titik tersebut (Hadi dan Sa'diyah (2004)).

6. Mengklasifikasikan kestabilan varietas pada Biplot AMMI2 Kestabilan varietas dapat diidentifikasi dengan pendekatan selang kepercayaan normal ganda yang berbentuk ellips dengan pusat $(0,0)$ pada skor komponen utama interaksinya. Adapun panjang jari-jari ellips dapat diperoleh dengan rumus:

$$
R_{i}= \pm \sqrt{\lambda_{i}} \sqrt{\frac{p(n-1)}{n(n-p)} F_{p, n-p(\alpha)}}
$$

keterangan:

$R_{i}:$ jari-jari pada sumbu KUIi

$\lambda_{i}$ : akar ciri dari matriks ragam peragam koordinat objek

$n$ : banyaknya pengamatan

$p$ : banyaknya komponen utama yang digunakan

$F_{p}, n-p(\alpha)$ : nilai tabel sebaran-F dengan $\mathrm{db} 1=p, \mathrm{db} 2=n-p$, dan $\alpha$ sebesar $1 \%$.

Biplot AMMI2 menunjukkan gambaran adaptasi varietas pada lokasi tertentu. Varietas yang berada di luar ellips merupakan varietas yang tidak stabil. Koordinat titik yang semakin mendekati pusat ellips menunjukkan bahwa semakin stabil pula varietas tersebut. Varietas-varietas yang mampu beradaptasi pada berbagai lokasi disebut varietas stabil, sedangkan varietas spesifik merupakan varietas-varietas yang hanya sesuai dengan kondisi lokasi tertentu (Mattjik et al. (2011)). 


\section{Metodologi}

\subsection{Data}

Penelitian ini menggunakan data primer yang diperoleh di Balai Pengkajian Teknologi Pertanian Jatim. Percobaan ini dilakukan pada tanaman padi gogo yang terdiri dari 15 varietas yang ditanam di 6 lokasi Taman Tanaman Percobaan (TTP) Pacitan yang disajikan pada Tabel I dan Tabel II. Rancangan percobaan yang digunakan adalah rancangan acak kelompok dengan dua ulangan. Peubah-peubah respon yang diamati berupa data peubah ganda yang merupakan sifat-sifat agronomis dari padi gogo yang disajikan pada Tabel III.

Tabel 1: Keterangan varietas padi gogo yang diamati

\begin{tabular}{cccc}
\hline Kode & Nama Varietas & Kode & Nama Varietas \\
\hline G1 & Inpago 7 & G9 & Gajah Mungkur \\
G2 & Inpago 8 & G10 & Slegreng TG \\
G3 & Inpago 8 IPB & G11 & Slegreng GK \\
G4 & Inpago 9 & G12 & Srijaya \\
G5 & Inpago 10 & G13 & Towuti \\
G6 & Situ Gintung & G14 & Merah Wangi \\
G7 & Situ Patenggang & G15 & Inpari 24 \\
G8 & Situ Bagendit & & \\
\hline
\end{tabular}

Tabel 2: Keterangan pada lokasi tanam padi gogo

\begin{tabular}{cc}
\hline Kode & Keterangan lokasi penanaman \\
\hline A1 & Pringkuku \\
A2 & Pagutan \\
A3 & Bulu \\
A4 & Modal \\
A5 & Ngaluran \\
A6 & Tempel \\
\hline
\end{tabular}

\subsection{Prosedur Analisis Data}

Adapun tahapan-tahapan analisis data pada penelitian ini untuk mengetahui varietas padi gogo yang stabil adalah sebagai berikut:

Tabel 3: Sifat-sifat agronomis padi gogo yang diamati berdasarkan produktifitas tanaman

\begin{tabular}{cc}
\hline Kode & keterangan peubah \\
\hline BKP & Bobot kering panen (kg/ha) \\
BB & Bobot brangkasan(ton $/$ ha) \\
JAP & Jumlah anakan produktif $(\%)$ \\
SPB & Serangan penyakit blast $(\mathrm{OPT})(\%)$ \\
UP & Umur panen (hari setelah tanam) $(\mathrm{HST})$ \\
\hline
\end{tabular}


1. Melakukan eksplorasi data untuk mengetahui gambaran umum dari data dengan menggunakan analisis deskriptif.

2. Melakukan uji asumsi analisis ragam terhadap masing-masing respon.

(a) Model bersifat aditif. Jika asumsi keaditifan model tidak terpenuhi akan berpengaruh terhadap keabsahan dan kesensitifan pengujian (Fadli et al. (2012)). Pengujian keaditifan model yang dapat digunakan adalah uji Tukey:

$$
\begin{gathered}
J K_{\text {nonaditif }}=\frac{Q^{2}}{r \Sigma\left(\bar{Y}_{i .}-\bar{Y}_{. .}\right)^{2} \Sigma\left(\bar{Y}_{. j}-\bar{Y}_{. .}\right)^{2}} \\
Q=\Sigma \Sigma\left(\bar{Y}_{i .}-\bar{Y}_{. .}\right)\left(\bar{Y}_{. j}-\bar{Y}_{. .}\right) Y_{i j} \\
F_{\text {hitung }}=\frac{J K_{\text {nonaditif }}}{\frac{J K_{\text {galat }}}{\text { dbgalat }}}
\end{gathered}
$$

dengan : $r=$ banyaknya ulangan

Apabila $F_{\text {hitung }} \leq F_{\alpha(1, \text { dbgalat })}$ maka keaditifan model dapat diterima, selainnya tolak keaditifan model (Aunuddin (2005))

(b) Kehomogenan ragam sisaan dapat diuji formal dengan menggunakan uji Barlett. Pengujian ini memiliki hipotesis sebagai beikut:

$H 0: \sigma_{1}^{2}=\sigma_{2}^{2}=\ldots=\sigma k^{2}$

$H 1$ : minimal ada satu ragam yang tidak sama

Statistik ujinya adalah:

$$
\begin{gathered}
\chi^{2}=2.3026\left(\left(\Sigma_{i}\left(r_{i}-1\right)\right) \log \left(s^{2}\right)-\Sigma_{i}\left(r_{i}-1\right) \log \left(s_{i}^{2}\right)\right) \\
s_{i}^{2}=\frac{\Sigma_{j}\left(Y_{j}-\bar{Y}_{i .}\right)^{2}}{r_{i}-1} \\
s^{2}=\frac{\Sigma\left(n_{i}-1\right) s_{i}^{2}}{N-t}
\end{gathered}
$$

jika nilai $\chi^{2}<\chi_{\alpha, k-1}^{2}$ maka ragam sisaan percobaan homogen atau terima $H 0$.

(c) Sisaan saling bebas. Keacakan sisaan percobaan dapat dibuat plot antara nilai dugaan sisaan percobaan dengan nilai dugaan respon (Mattjik dan Sumertajaya (2013)). Sisaan saling bebas dapat dikatakan apabila plot yang dibuat tidak membentuk suatu pola tertentu atau model yang jelas. Uji formal yang digunakan untuk pengujian sisaan saling bebas yaitu uji runs test.

(d) Sisaan menyebar normal. Pengujian terhadap sisaan menyebar normal yang akan digunakan yaitu uji Kolmogorov-Smirnov. Sisaan menyebar normal dapat dikatakan jika nilai nilai-p $\geq \alpha$.

3. Melakukan penggabungan respon dengan metode range equalization. Penggabungan respon dilakukan berdasarkan produktifitas dan daya tahan tanaman padi gogo.

4. Melakukan analisis ragam gabungan terhadap semua respon dari sifat - sifat agronomis padi gogo berdasarkan produktifitas dan daya tahan tanaman. Analisis ragam gabungan digunakan untuk mengetahui pengaruh varietas, pengaruh lokasi, 
dan pengaruh interaksi antara varietas dan lokasi tiap respon. Jika pengaruh interaksi antara varietas dan lokasi signifikan maka dapat dilanjutkan dengan analisis AMMI.

5. Melakukan analisis AMMI terhadap respon gabungan.

6. Interpretasi hasil dari analisis AMMI untuk mengetahui varietas padi gogo yang stabil dikeenam lokasi dari respon gabungan yang berdasarkan produktifitas dan daya tahan tanaman.

\section{Hasil dan Pembahasan}

\subsection{Eksplorasi Data}

Respon produktifitas tanaman padi dan daya tahan terhadap tanaman dapat dideskripsikan menurut lokasi dan varietas. Rataan tertinggi dari respon produktifitas padi yang terdiri dari BKP, BB, dan JAP berada pada lokasi A1 yaitu sebesar 3.42 (ton/ha), 14.11(ton/ha), dan $94.6 \%$. Respon produktifitas tanaman padi yang memiliki nilai rataan terendah pada respon BKP di lokasi A4 sebesar 2.77 (ton/ha), respon BB terdapat pada lokasi A6 sebesar 9.38, dan respon JAP terdapat pada lokasi A3 sebesar 90.52\%. Pola rataan dari respon BKP, BB, dan JAP menurut lokasi dapat dilihat pada Gambar 1.
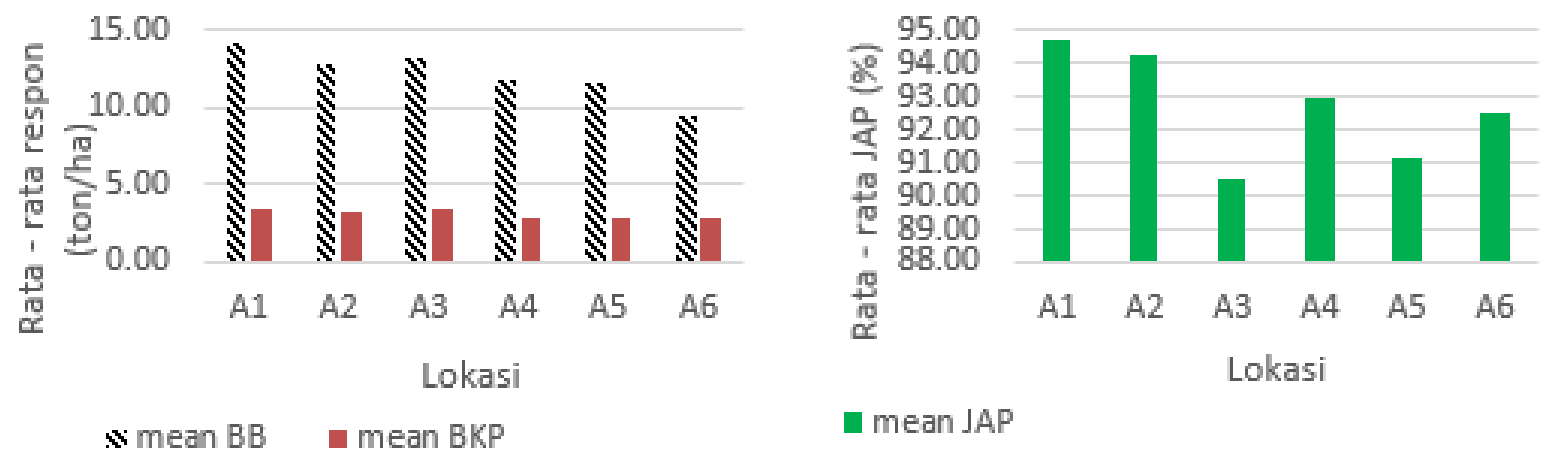

Gambar 1: Rataan respon BB, BKP, dan JAP menurut lokasi

Pada respon daya tahan tanaman yang terdiri dari respon UP dan SPB memiliki rataan tertinggi terdapat pada lokasi A5 yaitu sebesar 107.90 (HST) dan $40.57 \%$. Meskipun daya tahan tanaman memiliki rataan tertinggi pada lokasi yang sama dengan kondisi lingkungan yang berbeda, namun respon tersebut memiliki nilai rataan terendah pada lokasi yang berbeda. Pada respon UP dan SPB nilai rataan terendah di lokasi A6 sebesar 101.63 (HST) dan A4 sebesar 18\%. Pola rataan dari respon UP dan SPB dapat dilihat pada Gambar 2.

\subsection{Analisis Ragam Tiap Respon}

Asumsi-asumsi analisis ragam yang perlu diperhatikan antara lain keaditifan model, sisaan ragam yang homogen, sisaan saling bebas, dan sisaan menyebar normal. Pengujian asumsi terhadap semua respon yang digunakan, diperoleh hasil bahwa asumsi 

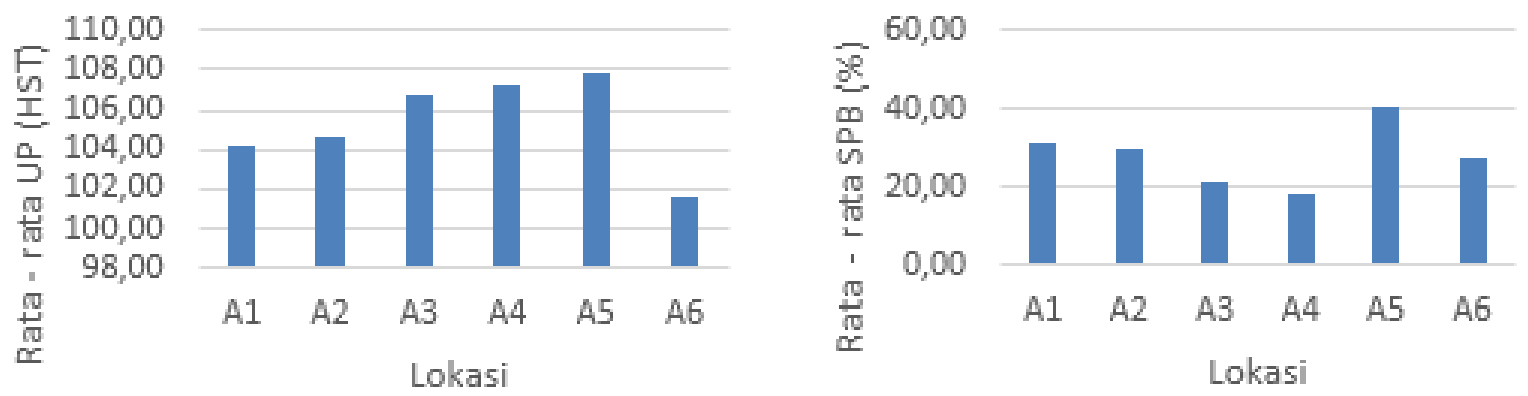

Gambar 2: Rataan respon UP dan SPB menurut lokasi

sisaan ragam yang homogen, sisaan saling bebas, dan sisaan menyebar normal dapat dipenuhi oleh data respon JAP, UP, dan SPB. Namun, pada respon BB dan BKP tidak memenuhi asumsi kehomogenan ragam sisaan dan sisaan saling bebas pada taraf nyata 1\%. Pelanggaran asumsi tersebut diperlukan penanganan dengan cara mentransformasikan data respon.

Pada respon BKP terdapat pelanggaran asumsi pada kehomogenan ragam sehingga dilakukan transformasi logaritma natural. Selain respon BKP, respon BB terdapat pelanggaran asumsi pada sisaan saling bebas. Hal ini dilakukan dengan menggunakan transformasi logaritma natural untuk memenuhi asumsi sisaan saling bebas. Hasil transformasi dari masing-masing respon dapat memenuhi asumsi pada taraf nyata sebesar $1 \%$.

Analisis ragam dapat dilakukan jika asumsi-asumsi telah terpenuhi. Berdasarkan pengujian asumsi yang telah dilakukan setiap respon telah memenuhi asumsi-asumsi analisis ragam. Sumber keragaman pada respon BB, JAP, dan UP memilki nilai-p $<\alpha$ sebesar 1\%, artinya cukup bukti untuk menyatakan bahwa masing-masing sumber keragaman berpengaruh terhadap tiap respon pada taraf nyata $1 \%$. Berbeda dengan respon BKP dan SPB, pengaruh kelompok tersarang pada lokasi memiliki nilai-p $>\alpha$ sebesar 1\%. Hal ini menunjukkan bahwa kelompok yang tersarang dilokasi tidak berpengaruh terhadap masing-masing repon pada taraf nyata $1 \%$.

\subsection{Penggabungan Respon}

Penelitian ini menggunakan metode range equalization untuk menggabungkan masing-masing respon menjadi dua respon, yaitu respon gabungan produktifitas tanaman (PT) dan respon gabungan daya tahan tanaman (DTT). Respon produktifitas tanaman merupakan gabungan dari respon BB, BKP, dan JAP. Hal ini berdasarkan semakin tinggi nilai respon $\mathrm{BB}$, BKP, dan JAP akan semakin baik tingkat produktifitasnya. Respon daya tahan tanaman merupakan gabungan dari respon UP dan SPB. Berbeda dengan respon produktifitas, respon daya tahan tanaman didasari oleh semakin rendah nilai respon UP dan SPB akan semakin baik daya tahan tanaman padi gogo. Metode range equalization diawali denegan mencari nilai SDII tiap respon. SDII tiap respon adalah sebagai berikut:

$\mathrm{BB}: S D I I_{1}=\frac{Y_{1 b}-8.4}{17.4-8.4} \mathrm{UP}: S D I I_{4}=\frac{Y_{4 b}-74}{125-74}$

BKP : $S D I I_{2}=\frac{Y_{2 b}-2.4}{7.8-2.4} \mathrm{SPB}: S D I I_{5}=\frac{Y_{5 b}-2.4}{89.6-2.4}$

JAP : $S D I I_{3}=\frac{Y_{3 b}-76.5}{100-76.5}$

Berdasarkan nilai SDII dari setiap respon awal maka respon gabungan dapat dihitung 
dengan mencari rata-rata SDII.

\subsection{Analisis Ragam Gabungan}

Pengujian asumsi analisis ragam gabungan sama dengan pengujian asumsi ragam tiap respon asal, yaitu keaditifan model, kehomogenan ragam, sisaan saling bebas, dan sisaan menyebar normal. Pada Tabel IV menunjukkan hasil pengujian asumsi analisis ragam masing-masing respon gabungan.

Tabel 4: Keterangan pada lokasi tanam padi gogo

\begin{tabular}{ccr}
\hline Pengujian Asumsi & $\begin{array}{c}\text { nilai-p } \\
\text { respon PT }\end{array}$ & $\begin{array}{r}\text { nilai-p } \\
\text { respon DTT }\end{array}$ \\
\hline Uji Barlett & 0.314 & 0.938 \\
Uji Run Test & 0.135 & 0.455 \\
Uji Kolmogorov-Smirnov & 0.150 & 0.150 \\
\hline
\end{tabular}

Pengujian asumsi kehomogenan ragam dilakukan menggunaan uji Barlett dengan taraf nyata 1\%. Hasil uji Barlett menunjukkan bahwa nilai p-value sebesar 0.314 untuk respon gabungan PT dan 0.938 untuk respon gabungan DTT (Gambar 5). Nilai nilai-p yang lebih besar dari 0.01 maka dapat disimpulkan bahwa kehomogenan ragam terpenuhi. Uji Runs test digunakan untuk menguji asumsi sisaan saling bebas. Berdasarkan uji Runs test diperoleh nilai-p sebesar 0.135 untuk respon gabungan PT sedangkan respon gabungan DTT diperoleh nilai-p 0.455. Jika nilai-p lebih besar dari 0.01 maka dapat disimpulkan bahwa sisaan saling bebas. Pengujian asumsi sisaan menyebar normal dilakukan menggunakan uji Kolmogorov-smirnov. Asumsi sisaan menyebar normal untuk kedua respon gabungan terpenuhi karena nilai-p sebesar 0.150 yang dihasilkan atau lebih besar dari 0.01.

Berdasarkan pengujian asumsi-asumsi analisis ragam gabungan yang terpenuhi pada taraf nyata $1 \%$, analisis ragam gabungan dapat dilakukan untuk mengetahui pengaruh varietas, lokasi, dan interaksinya. Tabel V dan Tabel VI menunjukkan hasil analisis ragam dari kedua respon gabungan. Kedua pengaruh utama yaitu varietas dan lokasi serta pengaruh interaksinya berpengaruh nyata terhadap respon pada taraf nyata $1 \%$. Sumber keragaman yang memberikan sumbangan terbesar adalah pengaruh varietas pada kedua respon gabungan, kemudian pengaruh lokasi dan interaksinya. Dengan demikian, produktifitas dan daya tahan tanaman bergantung pada penggunaan varietas dan lokasi tanam. Pengaruh interaksi yang nyata menunjukkan bahwa perbedaan rataan respon dari suatu varietas yang ditanam bergantung pada lokasi tertentu. Hal ini berarti jenis varietas tertentu akan tumbuh baik pada lokasi tertentu, tetapi belum sama halnya jika ditanam pada lokasi yang lain.

Pada seluruh respon gabungan, pengaruh interaksi antara varietas dengan lokasi telah signifikan. Hal ini ditunjukkan berdasarkan nilai-p yang kurang dari taraf nyata 1\%. Oleh karena itu, tahapan analisis dapat dilanjutkan dengan analisis AMMI.

\subsection{Analisis AMMI Berdasarkan Respon Gabungan}

\section{- Respon Gabungan Produktifitas Tanaman}

Penguraian nilai singular dari matriks dugaan pengaruh interaksi menghasilkan 5 akar ciri bukan nol yaitu 1.088, 0.382, 0.204, 0.0561, dan 0.041. Masing-masing 
Tabel 5: Analisis ragam untuk respon gabungan PT

\begin{tabular}{ccccc}
\hline Sumber & $\mathrm{db}$ & $\mathrm{JK}$ & $\mathrm{F}$ & nilai-p \\
\hline Varietas & 14 & 2.935 & 65.34 & 0.000 \\
Lokasi & 5 & 1.394 & 86.87 & 0.000 \\
Intraksi & 70 & 0.798 & 3.55 & 0.000 \\
kelompok(lokasi) & 6 & 0.172 & 8.91 & 0.000 \\
Error & 84 & 0.269 & & \\
Total & 179 & 5.567 & & \\
\hline
\end{tabular}

Tabel 6: Analisis ragam untuk respon gabungan DTT

\begin{tabular}{ccccc}
\hline Sumber & $\mathrm{db}$ & $\mathrm{JK}$ & $\mathrm{F}$ & nilai-p \\
\hline Varietas & 14 & 4.771 & 356.70 & 0.000 \\
Lokasi & 5 & 0.400 & 84.27 & 0.000 \\
Intraksi & 70 & 0.327 & 4.92 & 0.000 \\
kelompok(lokasi) & 6 & 0.011 & 1.89 & 0.092 \\
Error & 84 & 0.079 & & \\
Total & 179 & 5.589 & & \\
\hline
\end{tabular}

Tabel 7: Analisis ragam AMMI2 berdasarkan respon gabungan PT

\begin{tabular}{ccccc}
\hline Sumber & $\mathrm{db}$ & $\mathrm{JK}$ & $\mathrm{F}$ & nilai-p \\
\hline Varietas & 14 & 2.935 & 65.34 & 0.000 \\
Lokasi & 5 & 1.394 & 86.87 & 0.000 \\
Intraksi & 70 & 0.798 & 3.55 & 0.000 \\
KUI1 & 18 & 0.478 & 8.27 & 0.000 \\
KUI2 & 16 & 0.167 & 3.27 & 0.001 \\
simpangan & 36 & 0.153 & 1.32 & 1.000 \\
kelompok(lokasi) & 6 & 0.172 & 8.91 & 0.000 \\
Error & 84 & 0.269 & & \\
Total & 179 & 5.567 & & \\
\hline
\end{tabular}

akar ciri memiliki kontribusi keragaman pengaruh interaksi diantaranya 59.88\%, 21.03\%, 11.22\%, 5.61\%, dan 2.26\%. Berdasarkan nilai kontribusi keragaman tersebut terdapat dua komponen utama interaksi yang mampu menerangkan keragaman pengaruh interaksi, yaitu sebesar $80,91 \%$.

Berdasarkan metode posdictive succes diperoleh dua komponen utama interaksi yang signifikan pada taraf nyata $1 \%$ yaitu dengan nilai $\mathrm{F}$ sebesar 8.279 dan 3.270 seperti pada Tabel VII. Hal ini menunjukkan model AMMI dapat diterangkan dengan model AMMI2. Penggunaan model AMMI2 dikarenakan pengaruh interaksi direduksi dengan dua komponen.

Biplot AMMI1 pada Gambar 3 memberikan informasi bahwa G4 memiliki nilai paling tinggi dan G12 memiliki nilai paling rendah pada rataan respon gabungan PT. Pada G8 dan G10 memiliki rataan gabungan PT yang sama tetapi memiliki interaksi terhadap lokasi yang berbeda. Pengaruh interaksi positif pada varietas 


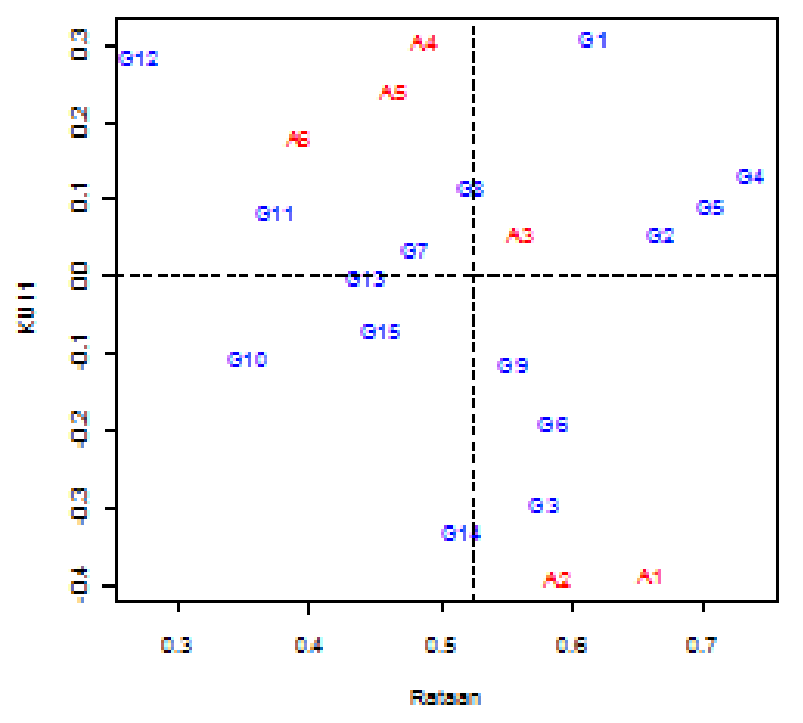

Gambar 3: Biplot AMMI1 rataan dengan KUI1 pada respon gabungan PT

dengan lokasi terjadi ketika skor KUI1 yang bertanda sama antara varietas dengan lokasi tanam, sedangkan jika tanda skor KUI1 berbeda maka pengaruh interaksinya negatif. Interaksi positif menunjukkan bahwa varietas tersebut dapat tumbuh dengan baik pada lokasi tanam yang memiliki tanda skor KUI1 sama. Varietas G1, G2, G4, G5, G7, G8, G11, dan G12 berinteraksi positif pada lokasi A3, A4, A5, dan A6. Varietas G3, G6, G9, G10, G13, G14, dan G15 berinteraksi positif pada lokasi A1 dan A2. Pada varietas G13, G7 dan G2 merupakan varietas-varietas dengan interaksi kecil terhadap lokasi tanam. Hal ini dikarenakan verietas-verietas tersebut memiliki skor KUI1 yang mendekati nol.

Biplot AMMI2 pada Gambar 4 memberikan informasi terkait struktur interaksi varietas dengan lokasi tanam dengan sumber keragaman sebesar 80.91\%. Bentuk ellips pada Gambar 4 merupakan pendekatan selang kepercayaan normal ganda yang menghasilkan jari-jari minor 0.11 dan jari-jari mayor 0.19. Varietas G2, G5, G7, G8, G9, dan G15 merupakan varietas yang stabil semua lokasi tanam karena berada dalam ellips atau selang kepercayaan normal ganda. Varietas lainnya yang berada diluar ellips merupakan varietas yang cenderung berinteraksi pada lokasi tanam tertentu atau varietas spesifik. Varietas G6 dan G14 memiliki sudut yang cukup kecil atau dengan lokasi A1, artinya varietas G6 dan G14 bersifat spesifik pada lokasi A1. Pada lokasi A2, varietas yang dapat berinterakasi dengan baik adalah G3, G6, dan G10. Varietas G1, G4, dan G11 spesifik pada lokasi A3 dan A5, sedangkan Varietas G12 dan G13 bersifat spesifik pada lokasi A4 dan A6.

Suatu varietas yang stabil dapat dilihat dari keselarasan nilai rata-rata hasil varietas yang stabil tersebut pada setiap lokasi dengan rata-rata keseluruhan varietas (Mindrajaya (2009)). Pada Gambar 5, rata-rata keenam varietas stabil yang diperoleh pada respon gabungan PT berada disekitar rata-rata keseluruhan varietas yang diuji disetiap lokasi. Pola perubahan rata-rata varietas G2, G5 dan G15 telah mengikuti pola perubahan rata-rata seluruh varietas, berbeda dengan pola perubahan rata-rata varietas G7, G8, dan G9 yang tidak mengikuti pola perubahan rata-rata seluruh varietas. Hal ini menunjukkan bahwa varietas G2, G5 dan G15 stabil secara signifikan pada respon gabungan PT. 


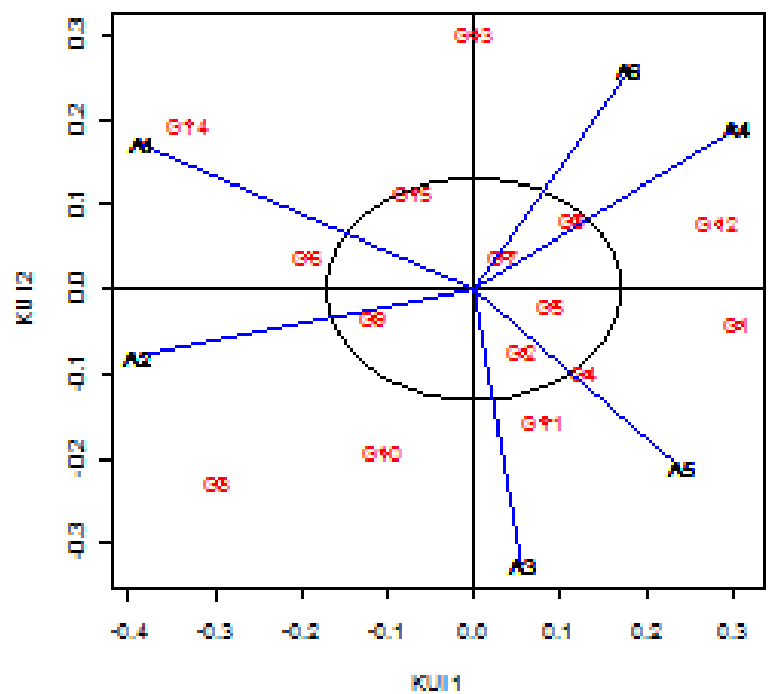

Gambar 4: Biplot AMMI2 KUI1 dengan KUI2 pada respon gabungan PT

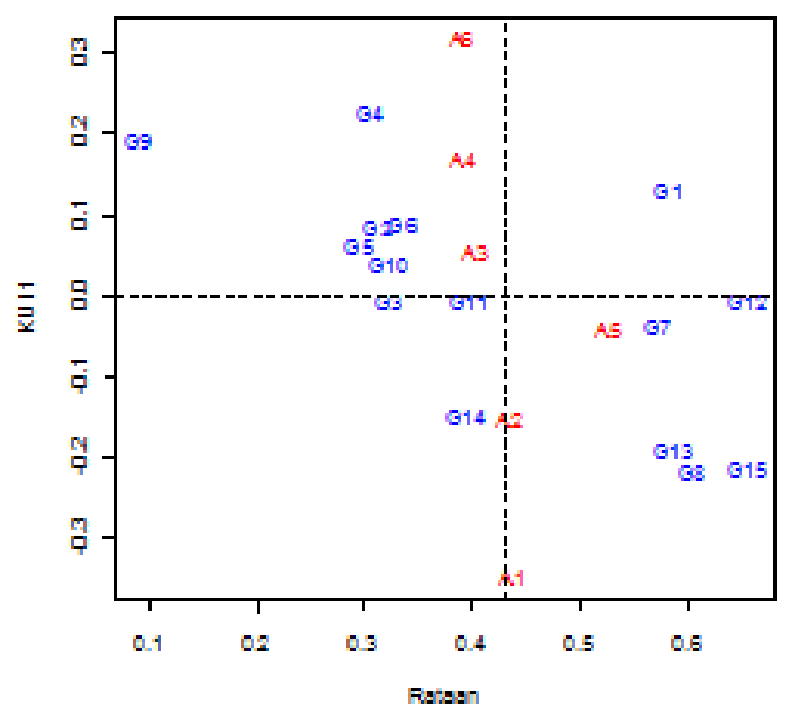

Gambar 5: Plot profil varietas stabil pada respon gabungan PT 
Tabel 8: Analisis ragam gabungan untuk respon gabungan DTT

\begin{tabular}{ccccc}
\hline Sumber & $\mathrm{db}$ & $\mathrm{JK}$ & $\mathrm{F}$ & nilai-p \\
\hline Varietas & 14 & 4.771 & 356.70 & 0.000 \\
Lokasi & 5 & 0.400 & 84.27 & 0.000 \\
Intraksi & 70 & 0.327 & 4.92 & 0.000 \\
KUI1 & 18 & 0.153 & 8.92 & 0.000 \\
KUI2 & 16 & 0.063 & 4.12 & 0.000 \\
KUI3 & 14 & 0.055 & 4.16 & 0.000 \\
KUI4 & 12 & 0.030 & 2.67 & 0.004 \\
KUI5 & 10 & 0.026 & 2.73 & 0.005 \\
kelompok(lokasi) & 6 & 0.011 & 1.89 & 0.092 \\
Error & 84 & 0.079 & & \\
Total & 179 & 5.589 & & \\
\hline
\end{tabular}

Varietas unggul pada respon gabungan PT ditunjukkan berdasarkan nilai dari ratarata varietas yang tinggi dan stabil pada semua lokasi. Rata-rata varietas yang semakin tinggi nilainya akan semakin baik tingkat produktivitas tanaman. Biplot AMMI1 terdapat tiga varietas yang memiliki nilai rata-rata tinggi yaitu varietas G2, G5, dan G4. Varietas G2 dan G5 merupakan varietas yang stabil pada semua lokasi (Gambar 6). Hal ini menunjukkan bahwa varietas G2 dan G5 merupakan varietas unggul pada semua lokasi berdasarakan respon gabungan PT. Varietas G4 memiliki nilai rata-rata yang tinggi, namun varietas G4 bersifat spesifik pada lokasi A5. Artinya, Varietas G4 merupakan varietas unggul pada lokasi A5.

\section{- Respon Gabungan Daya Tahan Tanaman}

Penguraian nilai singular dari matriks dugaan pengaruh interaksi menghasilkan 5 akar ciri bukan nol yaitu 0.659, 0.270, 0.239, 0.132, dan 0.112. Masing-masing akar ciri memiliki kontribusi keragaman pengaruh interaksi diantaranya $46.65 \%$, 19.16\%, 16.94\%, 9.31\%, dan 7.94\%. Berdasarkan nilai kontribusi keragaman tersebut terdapat tiga komponen utama interaksi yang mampu menerangkan keragaman pengaruh interaksi, yaitu sebesar $82.72 \%$. Secara metode posdictive succes diperoleh 5 komponen utama interaksi yang signifikan pada taraf nyata 1\% seperti pada Tabel VIII. Hal ini menunjukkan model AMMI dapat diterangkan dengan model AMMI2.

Biplot AMMI1 pada Gambar 6 memberikan informasi bahwa varietas G12 dan G15 memiliki nilai paling tinggi dan G9 memiliki nilai paling rendah pada rataan respon gabungan DTT. Terdapat varietas dengan memiliki nilai yang sama, namun interaksi terhadap lokasi tanam berbeda seperti G1 dengan G13 dan G3 dengan G10. Pada lokasi A3, A4, dan A6 memiliki interaksi positif terhadap varietas G1, G2, G4, G5, G6, G9, dan G10, sedangkan lokasi A1, A2, dan A5 berinteraksi positif terhadap varietas G3, G7, G8, G11, G12, G13, G14, dan G15. Pada varietas G3, G10, G11 dan G2 merupakan varietas-varietas dengan interaksi kecil terhadap lokasi tanam. Hal ini dikarenakan verietas-verietas tersebut memiliki skor KUI1 yang mendekati nol.

Biplot AMMI2 pada Gambar 7 didasari oleh KUI1 dan KUI2 dengan keragaman interaksi yang dapat dijelaskan sebesar $65.79 \%$. Bentuk ellips pada Gambar 7 


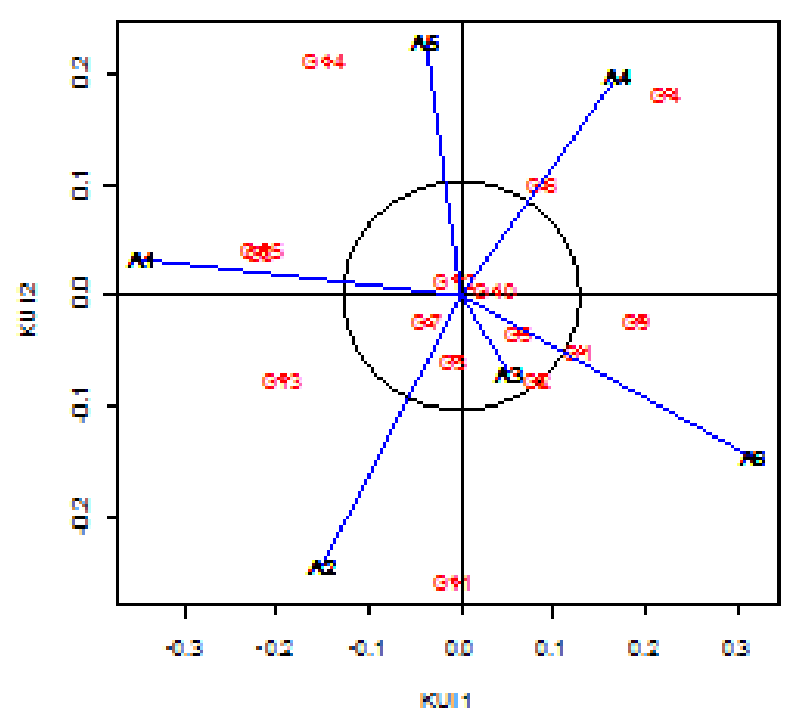

Gambar 6: Biplot AMMI1 rataan dengan KUI1 pada respon gabungan DTT

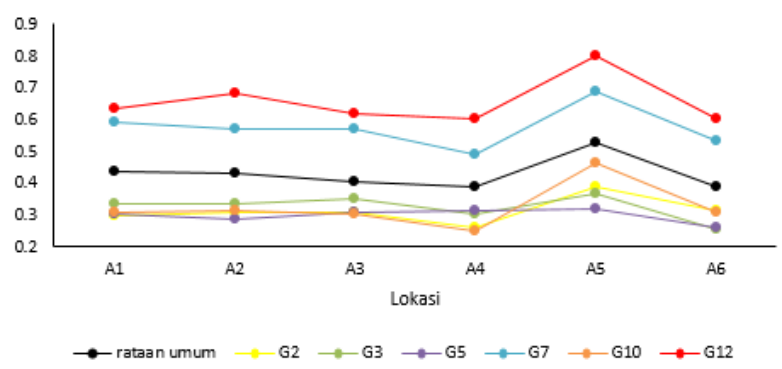

Gambar 7: Biplot AMMI2 KUI1 dengan KUI2 pada respon gabungan DTT

merupakan pendekatan selang kepercayaan normal ganda yang menghasilkan jari-jari minor 0.09 dan jari-jari mayor 0.14. Varietas-varietas yang stabil terdapat didalam ellips atau selang kepercayaan normal ganda, yaitu varietas G2, G3, G5, G7, G10, dan G12. Varietas-varietas ini memiliki produktifitas tanaman yang stabil pada semua lokasi tanam. Varietas G5, G8, dan G13 bersifat spesifik terhadap lokasi A1. Pada lokasi A2, varietas yang dapat berinteraksi dengan baik adalah G11 dan G13. Varietas G1, dan G9 spesifik pada lokasi A3 dan A6. Varietas G4 dan G6 bersifat spesifik pada lokasi A4, sedangkan lokasi A5 berinteraksi baik dengan varietas G14. Pada Gambar 8, rata-rata keenam varietas stabil yang diperoleh pada respon gabungan DTT berada disekitar rata-rata keseluruhan varietas yang diuji disetiap lokasi. Pola perubahan rata-rata keenam varietas telah mengikuti pola perubahan rata-rata seluruh varietas. Hal ini menunjukkan bahwa keenam varietas pada respon gabungan DTT stabil secara signifikan di semua lokasi.

Varietas unggul pada respon gabungan DTT ditunjukkan berdasarkan nilai dari rata-rata varietas yang rendah dan stabil pada semua lokasi. Rata-rata varietas yang semakin rendah nilainya akan semakin baik tingkat daya tahan tanaman. Biplot AMMI1 terdapat satu varietas yang memiliki nilai rata-rata rendah yaitu varietas G9. Vaietas G9 merupakan varietas yang bersifat spesifik pada lokasi A6. Hal ini menunjukkan bahwa varietas G9 varietas unggul pada lokasi A6. Biplot AMMI1 


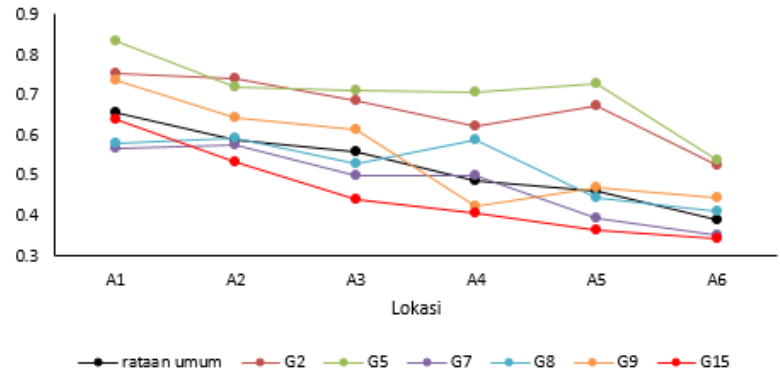

Gambar 8: Plot profil varietas stabil pada respon gabungan DTT

dan Biplot AMMI2 memberikan informasi varietas yang stabil dan memiliki nilai rata-rata rendah terdapat pada varietas G2, G3, G5, dan G10. Artinya, Varietas G2, G3, G5, dan G10 merupakan varietas unggul pada semua lokasi berdasarkan respon gabungan DTT.

Berdasarkan Biplot AMMI2 memberikan informasi kestabilan varietas dengan menggunakan selang kepercayaan normal ganda. Pada Biplot AMMI2 dari kedua respon gabungan terdapat varietas yang stabil secara konsisten, yaitu varietas G2, G5, dan G7. Varietas-varietas ini memiliki produktifitas dan daya tahan tanaman yang stabil pada semua lokasi tanam.

\section{Simpulan}

Analisis AMMI pada respon gabungan dengan menggunakan metode range equalization menghasilkan enam varietas stabil dari respon gabungan PT (produkifitas tanaman) maupun respon gabungan DTT (daya tahan tanaman), dan tiga varietas yang stabil secara konsisten pada kedua respon gabungan. Varietas yang stabil secara konsisten dari kedua respon gabungan yaitu varietas G2 (Inpago 8), G5 (Inpago 10), dan G7 (Situ Patenggang).

Varietas unggul merupakan varietas padi gogo yang stabil pada semua lokasi tanam serta memiliki nilai rata-rata respon produktivitas tanaman yang tinggi dan nilai rata-rata respon daya tahan tanaman yang rendah. Varietas G2 (Inpago 8) dan G5 (Inpago 10) merupakan varietas unggul berdasarkan kestabilan produktivitas dan daya tahan tanaman padi gogo. Varietas G4 (Inpago 9) merupakan varietas unggul pada lokasi A5 (Ngaluran) berdasarakan produktivitas tanaman, sedangkan varietas G9 (Gajah Mungkur) merupakan varietas unggul pada lokasi A6 (Tempel) berdasarkan daya tahan tanaman.

\section{Daftar Pustaka}

Aunuddin (2005). Statistika: Rancangan dan Analisis Data, IPB Press, Bogor(ID).

Fadli, G., Aunuddin dan Wigena, A. (2012). Penerapan komponen utama untuk pereduksi peubah pada ammi, Forum Statistika dan Komputasi 17(2): 24-2.

Hadi, A. dan Sa'diyah, H. (2004). Model ammi untuk interaksi varietas x lokasi, Jurnal Ilmu Dasar 5(1): 33-41. 
Idris dan Baharudin (2015). Analisis data hasil pengujian multilokasi padi sawah menggunakan model ammi, Informatika Pertanian 24(1): 17-30.

Mattjik, A. dan Sumertajaya, I. (2013). Perancangan Percobaan dengan Aplikasi SAS dan Minitab Jilid 1, IPB Press, Bogor(ID).

Mattjik, A., Sumertajaya, I., Hadi, A. dan Wibawa, G. (2011). Pemodelan AMMI: Kini dan Yang Akan Datang Ed-1, IPB Press, Bogor(ID).

Mindrajaya, I. (2009). Analisis interaksi geenotip $x$ lingkungan menggunakan model persamaan struktural [tesis], institut Pertanian Bogor, Bogor(ID).

Purba, R. dan Giametri, Y. (2017). Keragaan hasil dan keuntungan usahatani padi dengan introduksi varietas unggul di provinsi banten, Jurnal Ilmu Pertanian 22(1): 13-19.

Rumakubis, M. (2012). Analisis stabilitas delapan varietas tanaman jahe di tiga lokasi di jawa barat [skripsi], Institut Pertanian Bogor, Bogor(ID).

Sujiprihati, S., Syukur, M. dan Yuniarti Nasution, R. (2006). Analisis stabilitas hasil tujuh populasi jagung manis menggunakan metode additive main effect multiplicative interaction (ammi), Bul Agron 34(2): 93-97.

Sumertajaya, I. (1998). Perbandingan model AMMI dn regresi linier untuk menerangkan pengaruh interaksi percobaan multilokasi [tesis], institut Pertanian Bogor, Bogor(ID).

Sumertajaya, I. (2005). Kajian pengaruh inter block dan interaksi pada uji Lokasi ganda dan respon ganda [disertasi], Fakultas MIPA, IPB, Bogor(ID).

Suwarno, E., Lubis, A., Hairmansis dan Nasution, A. (2008). Pembentukan paket 20 varietas padi gogo untuk mengendalikan penyakit blast, Prosiding Simposium V Tanaman Pangan Inovasi teknologi Tanaman 342(2): 257-268. 